\title{
Karakteristik Visual Busana Kebaya Ibu Negara Indonesia
}

\author{
SUCIATI, AGUS SACHARI, KAHFIATI KAHDAR, ${ }^{2}$ ACHMAD SYARIF ${ }^{4}$ \\ 1,2,3,4. Program Doktor Ilmu Seni Rupa dan Desain, Fakultas Seni Rupa dan Desain, \\ Institut Teknologi Bandung, Jalan Ganesha No. 10, Bandung, 40132, Indonesia \\ E-mail: suciati@upi.edu
}

Busana Ibu Negara mempresentasikan citra perempuan Indonesia. Busana Kebaya Ibu Negara merupakan Busana Nasional yang keberadaannya sebagai salah satu identitas visual yang memiliki karakteristik tertentu sebagai identitas visual nasional. Tujuan penelitian ini, mendeskripsikan secara visual karakteristik Busana Kebaya Ibu Negara sebagai busana nasional. Metode penelitian historis (latarbelakang budaya, pendidikan, dan lingkungan pergaulan) digunakan sebagai cara untuk mengungkapkan karakteristik Busana Kebaya Ibu Negara Indonesia. Kajian ini menunjukkan adanya karakteristik Busana Kebaya Ibu Negara yang meliputi hair do, make up, busana bagian atas (kebaya nasional), busana bagian bawah (kain panjang/kain tradisional daerah Indonesia), beserta pemakaian aksessories dan millineriesnya. Karakteristik Busana Kebaya Ibu Negara meliputi karakteristik bentuk fisik, ragam hias, bahan, ukuran, dan cara pakai. Kesimpulan dari kajian ini adalah adanya pengelompokkan jenis busana kebaya dari berbagai busana kebaya yang popular di Indonesia, dan adanya ciri-ciri tertentu pada busana kebaya untuk Ibu Negara yang umumnya menunjukkan Busana Nasional perempuan Indonesia.

\section{Visual Characteristics of Kebaya Wore by Indonesian 1st Lady}

Indonesian 1st Lady's dress can be stated as the representation of Indonesian women's image. One of Indonesian 1st lady's dress known as kebaya is becoming one type of national dress with visual identity which has certain characteristics of national visual identity. The purpose of this study is to describe the characteristics of Indonesian 1st lady dress as national dress based on visual perspective. Historically research methods (cultural background, education and socialization environment) are used in order to reveal the characteristics of kebaya wore by Indonesian 1st lady. This study shows the characteristics of kebaya worn by Indonesian 1st lady consists of hair do, make up, upper part of clothes (national kebaya), lower part of clothes (long woven/Indonesian traditional woven), accompanied with accessories used and millieneries. The characteristics of kebaya wore by Indonesian 1st lady consist of the characteristics of physical shapes, material, size and the way of wearing it. The conclusion of this study shows the categorization of kebaya types based on popular kebaya found in Indonesia, and also the existence of certain characteristics of kebaya wore by Indonesian 1st lady which commonly referred to national dress of Indonesian women.

Keywords: Indonesian 1st lady dress, kebaya, national dress, Indonesian women's image, lady, national visual identity, characteristics 
Busana Kebaya merupakan salah satu jenis gaya berbusana yang berkembang di Indonesia. Busana Kebaya terdiri dari beragam desain. Umumnya di kenal Busana Kebaya tradisional (busana dearah Indonesia), Busana Kebaya modifikasi atau moderen, Busana Kebaya muslimah, dan Busana Kebaya Nasional. Kondisi ini memunculkan berbagai desain Busana Kebaya sesuai fungsi dan kesempatan pemakaiannya. Pengelompokkan Busana Kebaya tersebut didasarkan pada karakteristik masing-masing desain Busana Kebaya. Busana Kebaya Nasional terkait dengan penampilan Ibu Negara sebagai representasi wanita Indonesia yang kerap memakai Busana Kebaya pada acara formal kenegaraan yang mencerminkan identitas visual nasional. Telaah jenis Busana Kebaya sesuai pengelompokkannya dapat diamati melalui karakteristik Busana Kebaya tersebut.

Karakteristik visual menjadi identitas visual. Identitas berasal dari bahasa Inggris yaitu identity yang artinya ciri-ciri atau tanda-tanda. Identitas diartikan sebagai sifat khas, yang menerangkan sesuatu dan sesuai dengan kesadaran diri pribadi sendiri, golongan sendiri, kelompok sendiri atau negara sendiri. Identitas nasional merupakan identitas yang melekat pada kelompok-kelompok yang lebih besar yang diikat oleh kesamaan-kesamaan, baik fisik (budaya, agama, dan bahasa) maupun non fisik (keinginan, cita-cita dan tujuan). Identitas Nasional merupakan wujud nilai-nilai budaya yang tumbuh dan berkembang dalam berbagai aspek kehidupan dari ratusan suku yang dihimpun menjadi satu kesatuan Indonesia menjadi kebudayaan Nasional dengan acuan Pancasila dan jiwa Bhinneka Tunggal Ika.

Identitas Nasional dapat diartikan sebagai ciri, karakter, dan sifat khas suatu bangsa dan negara. Identitas Nasional tersebut pada dasarnya menunjuk pada identitas-identitas yang sifatnya Nasional. Identitas Nasional bersifat buatan (karena identitas nasional itu dibuat, dibentuk dan disepakati oleh warga bangsa sebagai identitasnya setelah mereka bernegara) dan bersifat sekunder (karena lahir, kemudian bila dibandingkan dengan identitas kesukubangsaan yang memang telah dimiliki warga bangsa itu secara askriptif). Sebelum memiliki identitas nasional, warga bangsa telah memiliki identitas primer yaitu identitas kesukubangsaan (budaya etnik Nusantara).
Identitas nasional berkorelasi dengan jati diri bangsa atau kepribadian suatu bangsa. Kepribadian sebagai suatu identitas adalah keseluruhan atau totalitas dari faktor-faktor biologis, psikologis dan sosiologis yang mendasari tingkah laku individu. Kepribadian tercermin pada keseluruhan tingkah laku seseorang dalam hubungan dengan manusia lain. Kepribadian sebagai suatu identitas nasional suatu bangsa, adalah keseluruhan kepribadian individu-individu sebagai unsur yang membentuk bangsa tersebut. Identitas nasional suatu bangsa tidak dapat dipisahkan dengan pengertian peoples character, national character atau national identity yang harus dipahami dalam konteks dinamis. Keterkaiatan antara Busana Kebaya, peranan Ibu Negara, dan identitas Nasional dapat diamati pada uraian bagan halaman 222 berikut

Ibu Negara termasuk ke dalam kelompok negarawan. Ibu Negara sebagai negarawan perlu memperhatikan penampilannya, yang salahsatunya tentu harus selalu tampil indah. Keindahan bagi seorang negarawan seperti dijelaskan Inu Kencana (2003) bahwa untuk menilai seni estetika seorang negarawan (dalam Islam) harus dipertanyakan cipta, rasa dan karsanya yang biasa disebut dengan EQ (Emotional Question) dan dipilah-pilah keberadaannya. Keindahan penampilan terkait dengan seni sebagai kekuatan pribadi seseorang yang kreatif, ditambah dengan keahlian yang bersangkutan dalam menampilkan tugas pekerjaannya. Keindahan/seni merupakan kemampuan dan kemahiran seseorang untuk mewujudkan cipta, rasa dan karsa yang dimiliki yang bersangkutan dalam tugas dan fungsinya sebagai seniman. Kemampuan ini merupakan bakat alamiah yang dibawa sejak lahir (karunia Allah), dan diperoleh dari lingkungan (pendidikan, agama, pergaulan, praktek sehar-hari suatu kelompok etnis). Penampilan Ibu Negara saat berbusana Kebaya, dapat memainkan perannya terhadap khalayak bangsa Indonesia karena kemampuannya dalam membujuk (persuasif), mendorong (motivatif), menghubungkan (komunikatif), memfasilitasi, mematangkan hubungan dan teladan yang menjadi contoh bangsa Indonesia.

Busana kebaya sebagai Busana Nasional perempuan Indonesia terkait dengan hubungan integritas bangsa dengan keindahan, wujud penyampaian keindahan, dan nilai seni. Salahsatu landasan untuk membangun persatuan bangsa adalah hadirnya hubungan 
antar suku bangsa yang bersifat saling memahami, saling mengapresiasi, bahkan dapat saling meminjam berkenaan dengan khasanah budaya, melalui pembelajaran sedalam-dalamnya mengenai bentukbentuk budaya, teknik penyajian seni dan pemikiran-pemikiran atau konsep-konsep yang melandasinya.

Berbusana kebaya nasional merupakan wujud konsep seni yang tidak lain perwujudan konsep rasa. Rasa adalah pengalaman penghayatan seni di mana kesiapan akal, budi dan emosi menyatu untuk mewujudkan penikmatan seni. Penikmatan seni sama hakekatnya dengan penikmatan penghayatan religius.
Dalam kedua hal itu keterikatan pada penyerapan indrawi sudah dilampaui. Pencapaian keindahan seni adalah substansi ekspresi seni menyentuh dan merangsang panca-indera (Edi Sedyawaty: 2010).

Pemahaman nilai seni dan integritas bangsa artinya fungsi nilai-nilai estetika Nusantara dalam mencegah disintegrasi bangsa. Integritas bangsa mengacu kepada urusan-urusan politik, keamanan dan ekonomi. Pemakaian Busana Kebaya Nasional berperan cukup besar dalam mengobarkan rasa nasionalisme dan sanggup mempersatukan bangsa dalam rasa, mengisi kemerdekaan, membina persatuan secara berkelanjutan, membina keanekaragaman budaya Indonesia, menghadapi tantangan negatif budaya asing.

Gambar 1. Bagan keterkaiatan antara Busana Kebaya, peranan Ibu Negara, dan identitas Nasional

Sejarah:

1. Pembentukan,

Perkembangan,

Perubahan desain

Busana Kebaya sebagai

busana Nasional

2. Emansipasi wanita Indonesia

3. Masa Pemerintahan Presiden R.I
Fakta empirik:

1. Identitas nasional

a. Unsur:

b. Jenis:

1) Identitas Fundamental:

2) Identitas Instrumental: Resmi:

a) lambang negara (Burung Garuda)

b) bendera negara (Sang Saka Merah Putih)

Tidak resmi:

Busana: batik, peci, busana kebaya

3) Identitas Alamiah:

2 Ideologi perempuan:

a. Kodrati (rahim/peranakan)

1) Istri

2) Ibu

3) Teman hidup

b. Nonkodrati (fisik)

1) pekerja

2) anggota masyarakat.

3. Busana Kebaya Ibu Negara Indonesia:

a. Fatmawati

b. R.Ay. Siti Hartinah

c. Hasri Ainun

d. Sinta Nuriyah

e. Kristiani Herrawati
Identitas visual

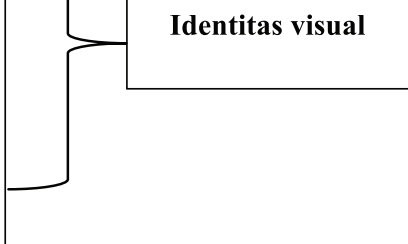

Kedudukan perempuan:

1. Lambang keabadian hidup

2. Keabadian dunia

3. Agen pendidik:

I

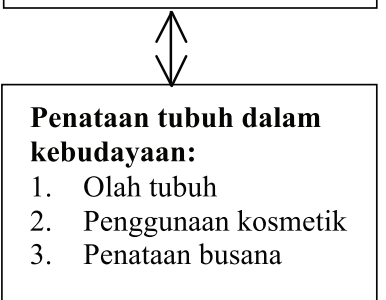


antar suku bangsa yang bersifat saling memahami, saling mengapresiasi, bahkan dapat saling meminjam berkenaan dengan khasanah budaya, melalui pembelajaran sedalam-dalamnya mengenai bentukbentuk budaya, teknik penyajian seni dan pemikiran-pemikiran atau konsep-konsep yang melandasinya.

Berbusana kebaya nasional merupakan wujud konsep seni yang tidak lain perwujudan konsep rasa. Rasa adalah pengalaman penghayatan seni di mana kesiapan akal, budi dan emosi menyatu untuk mewujudkan penikmatan seni. Penikmatan seni sama hakekatnya dengan penikmatan penghayatan religius.
Dalam kedua hal itu keterikatan pada penyerapan indrawi sudah dilampaui. Pencapaian keindahan seni adalah substansi ekspresi seni menyentuh dan merangsang panca-indera (Edi Sedyawaty: 2010).

Pemahaman nilai seni dan integritas bangsa artinya fungsi nilai-nilai estetika Nusantara dalam mencegah disintegrasi bangsa. Integritas bangsa mengacu kepada urusan-urusan politik, keamanan dan ekonomi. Pemakaian Busana Kebaya Nasional berperan cukup besar dalam mengobarkan rasa nasionalisme dan sanggup mempersatukan bangsa dalam rasa, mengisi kemerdekaan, membina persatuan secara berkelanjutan, membina keanekaragaman budaya Indonesia, menghadapi tantangan negatif budaya asing.

Gambar 1. Bagan keterkaiatan antara Busana Kebaya, peranan Ibu Negara, dan identitas Nasional

Sejarah:

1. Pembentukan,

Perkembangan,

Perubahan desain

Busana Kebaya sebagai

busana Nasional

2. Emansipasi wanita Indonesia

3. Masa Pemerintahan Presiden R.I
Fakta empirik:

1. Identitas nasional

a. Unsur:

b. Jenis:

1) Identitas Fundamental:

2) Identitas Instrumental: Resmi:

a) lambang negara (Burung Garuda)

b) bendera negara (Sang Saka Merah Putih)

Tidak resmi:

Busana: batik, peci, busana kebaya

3) Identitas Alamiah:

2 Ideologi perempuan:

a. Kodrati (rahim/peranakan)

1) Istri

2) $\mathrm{Ibu}$

3) Teman hidup

b. Nonkodrati (fisik)

1) pekerja

2) anggota masyarakat.

3. Busana Kebaya Ibu Negara Indonesia:

a. Fatmawati

b. R.Ay. Siti Hartinah

c. Hasri Ainun

d. Sinta Nuriyah

e. Kristiani Herrawati 
antar suku bangsa yang bersifat saling memahami, saling mengapresiasi, bahkan dapat saling meminjam berkenaan dengan khasanah budaya, melalui pembelajaran sedalam-dalamnya mengenai bentukbentuk budaya, teknik penyajian seni dan pemikiran-pemikiran atau konsep-konsep yang melandasinya.

Berbusana kebaya nasional merupakan wujud konsep seni yang tidak lain perwujudan konsep rasa. Rasa adalah pengalaman penghayatan seni di mana kesiapan akal, budi dan emosi menyatu untuk mewujudkan penikmatan seni. Penikmatan seni sama hakekatnya dengan penikmatan penghayatan religius.
Dalam kedua hal itu keterikatan pada penyerapan indrawi sudah dilampaui. Pencapaian keindahan seni adalah substansi ekspresi seni menyentuh dan merangsang panca-indera (Edi Sedyawaty: 2010).

Pemahaman nilai seni dan integritas bangsa artinya fungsi nilai-nilai estetika Nusantara dalam mencegah disintegrasi bangsa. Integritas bangsa mengacu kepada urusan-urusan politik, keamanan dan ekonomi. Pemakaian Busana Kebaya Nasional berperan cukup besar dalam mengobarkan rasa nasionalisme dan sanggup mempersatukan bangsa dalam rasa, mengisi kemerdekaan, membina persatuan secara berkelanjutan, membina keanekaragaman budaya Indonesia, menghadapi tantangan negatif budaya asing.

Gambar 1. Bagan keterkaiatan antara Busana Kebaya, peranan Ibu Negara, dan identitas Nasional

Sejarah:

1. Pembentukan,

Perkembangan,

Perubahan desain

Busana Kebaya sebagai

busana Nasional

2. Emansipasi wanita Indonesia

3. Masa Pemerintahan Presiden R.I
Fakta empirik:

1. Identitas nasional

a. Unsur:

b. Jenis:

1) Identitas Fundamental:

2) Identitas Instrumental: Resmi:

a) lambang negara (Burung Garuda)

b) bendera negara (Sang Saka Merah Putih)

Tidak resmi:

Busana: batik, peci, busana kebaya

3) Identitas Alamiah:

2 Ideologi perempuan:

a. Kodrati (rahim/peranakan)

1) Istri

2) Ibu

3) Teman hidup

b. Nonkodrati (fisik)

1) pekerja

2) anggota masyarakat.

3. Busana Kebaya Ibu Negara Indonesia:

a. Fatmawati

b. R.Ay. Siti Hartinah

c. Hasri Ainun

d. Sinta Nuriyah

e. Kristiani Herrawati 
berselendang. sarung klasik seperti songket dan baju kurung atau kebaya panjang dan selendang yang senada dengan sarung. Busana bersifat klasik dipakai untuk acara resmi, acara kenegaraan, upacara penyerahan surat-surat kepercayaan.

2. semi klasik/kombinasi, yaitu kain berwiru atau sarung yang dikenakan dengan kebaya pendek atau panjang dengan variasi model dan selendang. busana semi klasik untuk acara resmi di perwakilan, undangan pejabat negara penerima, upacara pemakaman, pelantikan

3. moderen, kain batik sutra tanpa wiru atau sarung yang dikenakan dengan kebaya moderen dengan atau tanpa selendang, untuk acara tidak resmi tapi harus dihadiri seperti jamuan minum teh atau kopi, menonton konser atau opera.

\section{Jenis Pakaian Nasional:}

1. Kain batik wiru dengan kebaya pendek tanpa bef (kutubaru) dari Sunda

2. Kain batik wiru dengan kebaya panjang atau pendek tanpa bef (kutubaru) dari Jawa

3. Sarung tenun atau songket dengan baju kurung atau baju panjang sumatra

4. Sarung batik dua warna pagi sore dari pekalon gan dengan kebaya putih renda dari Manado

5. Sarung batik bertumpal di depan dengan kebaya encim polos dari Betawi

6. Sarung tenun dengan kebaya putih dari Ambon

7. Sarung tenun atau songket dengan baju kurung pendek dari Kalimantan

8. Kain Bali dengan kebaya model Kartini dan selendang diikat di pinggang dari Bali

9. Baju Bodo yang dimodifikasi dari sulawesi selatan

10.Sarung batik panjang sebetis dengan model Kartini dengan lengan $3 / 4$ dari Madura

Mally Maeliah (2004:1) menguraikan beberapa hal yang terkait dengan busana Nasional yaitu: Busana Nasional ada untuk pria dan wanita, dalam kenyataannya sekarang yang dikenal adalah busana Nasional untuk wanita yang diambil dari busana daerah Jawa atau Sunda, sedangkan untuk pria tidak lagi mengambil dari busana tradisional daerah. Busana Nasional adalah satu stel busana khas Indonesia yang sudah disepakati bersama oleh para ahli busana dan bangsa Indonesia. Busana Nasional untuk wanita terdiri dari kain panjang atau sarung, kebaya dan selendang, sedangkan untuk pria terdiri dari pantalon, dan kemeja atau safari batik.
Lebih lanjut Mally Maeliah (2004:2-3) menjelaskan perkembangan desain busana Nasional, bahwa:

Busana Nasional berkembang sesuai dengan perkem bangan mode dan perkembangan industri tekstil. Perkembangan pada busana Nasional tetap tidak meninggalkan ciri khas jenis busananya sepeti terdiri dari kain atau sarung dan kebaya, perkembangannya berada pad acara menggunakan kain atau sarung yaitu yang biasanya langsung disampirkan pada badan tanpa di jahit, maka sekarang dapat dipergunakan kain atau sarung yang sudah dijahit tanpa digunting. Perubahan pada kebaya umumnya berada pada 1)model lengan, 2)model bagian belahan muka (berkancing bungkus dengan sengkelit yang dibuat dari kain yang sama dengan kain kebaya), 3)model lingkar lubang leher, 4)material bahan untuk kebaya (dihias pada bagian-bagaian badan dan lengan dengan bordiran sisi, serak merambat.

Peraturan lain adalah P.P No.8 Tahun 1987 tentang pengantar, bahwa:

yang dimaksud dengan Pejabat Negara adalah sebagaimana tersebut dalam Undang-undang Nomor 8 Tahun 1974 tentang Pokok-pokok Kepegawaian, yaitu Presiden dan Wakil Presiden; Anggota Badan Permusyawaratan/Perwakilan Rakyat; Anggota Badan Pemeriksa eratnya keterkaitan antara protokol dan acara-acara yang bersangkutan, yaitu acara kenegaraan ataupun acara resmi. Keprotokolan dalam acara kenegaraan atau acara resmi tersebut harus tetap memperhatikan nilai sosial dan budaya bangsa Indonesia sendiri yang berkembang, tanpa mengabai kan kebiasaan-kebiasaan yang berlaku di kalangan internasional.

P.P No.8 Tahun 1987 Pasal 2, menyebutkan bahwa: Dalam Undang-undang ini acara kenegaraan antara lain berupa Hari Ulang Tahun Proklamasi Kemerde kaan Negara Republik Indonesia tanggal 17 Agustus 1945, dan acara resmi antara lain berupa peresmian proyek-proyek

P.P No.8 Tahun 1987 Pasal 5 ayat (1), menyebutkan bahwa:

Yang dimaksud dengan tata upacara adalah aturan untuk melaksanakan upacara dalam acara kenegaraan atau acara resmi. Tata upacara meliputi antara lain tata bendera kebangsaan, lagu kebangsaan, pakaian upacara, untuk tercapainya keseragaman, kelancaran, ketertiban, dan kekhidmatan upacara.

UURI (Undang-undang Republik Indonesia) No.9 tahun 2010 BAB I Ketentuan Umum Pasal 1 ayat (2) dan (3) menyebutkan:

1. Acara Kenegaraan adalah acara yang diatur dan dilaksanakan oleh panitia negara secara terpusat, dihadiri oleh Presiden dan/atau Wakil Presiden, serta Pejabat Negara dan undangan lain. 
2. Acara Resmi adalah acara yang diatur dan dilak sanakan oleh pemerintah atau lembaga negara dalam melaksanakan tugas dan fungsi tertentu dan dihadiri oleh Pejabat Negara dan/atau Pejabat Pemerintahan serta undangan lain.

Selain itu pada BAB III pasal 5 ayat (2) disebutkan "Acara Kenegaraan dan Acara Resmi dapat berupa upacara bendera atau bukan upacara bendera.

Sedangkan pada Pasal 14 ayat (1) dan (2) disebutkan: 1. Pejabat Negara, Pejabat Pemerintahan, perwakilan negara asing dan/atau organisasi internasional, serta Tokoh Masyarakat Tertentu dalam Acara Kenegaraan dan/atau Acara Resmi dapat didampingi istri atau suami.

2. Istri atau suami sebagaimana dimaksud pada ayat

(1) menempati urutan sesuai Tata Tempat suami atau istri.

Peraturan tersebut di atas, pada Bab V mengenai Tata Upacara, Bagian 1 tentang upacara bendera, pada pasal 16 menyebutkan:

Upacara bendera hanya dapat dilaksanakan untuk

Acara Kenegaraan atau Acara Resmi:

1. Hari Ulang Tahun Proklamasi Kemerdekaan Republik Indonesia;

2. Hari besar nasional;

3. Hari ulang tahun lahirnya lembaga negara;

4. Hari ulang tahun lahirnya instansi pemerintah; dan

5. Hari ulang tahun lahirnya provinsi dan kabupaten/kota.

sedangkan mengenai tata busana, pada undang-undang tersebut termuat pada pasal 17 butir ke-4 yang menyebutkan:

Tata upacara bendera dalam penyelenggaraan Acara

Kenegaraan dan Acara Resmi meliputi:

1.Tata urutan dalam upacara bendera;

2.Tata bendera negara dalam upacara bendera;

3.Tata lagu kebangsaan dalam upacara bendera; dan

4.Tata pakaian dalam upacara bendera.

sedangkan mengenai tata busana, pada undang-undang tersebut termuat pada pasal 17 butir ke- 4 yang menyebutkan:

Tata upacara bendera dalam penyelenggaraan Acara

Kenegaraan dan Acara Resmi meliputi:

1. Tata urutan dalam upacara bendera;

2. Tata bendera negara dalam upacara bendera;

3. Tata lagu kebangsaan dalam upacara bendera; dan

4. Tata pakaian dalam upacara bendera.

Busana Kebaya Nasional dapat di identifikasi sebagai ciri-ciri berdasarkan bentuk fisik dan teknik jahitnya, yaitu:

1. Hair-do (tata rambut berbentuk sanggul)

a. Dipilih Ukel Konde yakni sanggul model

Sangul Jawa dengan 3 (tiga) tusuk konde yaitu di bagian kiri dan kanan masing-masing satu tusuk konde serta satu tusuk konde kecil (sindik, di tengah atas sanggul).

b. Bunga melati dironce membentuk lingkaran $(10 \mathrm{~cm})$, disimpan di atas sindik

c. Sunggar atau rambut di atas telinga yang dibentuk (tidak merupakan keharusan) karena memakai gaya Jawa Barat pun boleh saja (tanpa sunggar)

d. Bentuk sanggul disesuaikan dengan jenis kebaya

e.Ukuran sanggul disesuaikan dengan ukuran tubuh pemakai

f. Pelengkap sanggul disesuaikan dengan bentuk sanggul

2. Make-up (tata rias wajah) disesuaikan dengan bentuk wajah

3. Kebaya (blouse berbentuk kebaya sebagai busana bagian atas)

a. blouse berlengan panjang yang dipakai di sebe lah luar kain panjang atau sarung,

b. bagian pergelangan tangan melebar atau menyempit.

c. berkrah setali (ber-surawe)

d. belahan penutup dan pembuka (pada bagian depan kebaya) baik langsung tanpa bef atau kutu baru maupun menggunakan penutup bef atau kutu baru dengan peniti atau kancing e. panjangnya berkisar sekitar pinggul dengan model ujung belahan muka kebaya sejajar garis panggul sampai ke lutut

f. material bahan kebaya sebaiknya bertekstur halus seperti shantung, lace atau brocade (kain renda), lame, lurik, voile, organdi, sutra, tile, sifon dan katun (kain tidak transparan) teknik menjahit kebaya yaitu teknik menyambung dengan setik balik, dan bagian bawah kebaya dan lengan disom (teknik jahit pada kebaya klasik). Dewasa ini, apabila menggunakan furing disele saikan dengan kampuh tutup dan diobras.

4. Kain panjang atau sarung (sebagai busana pada bagian bawah)

a. Kain panjang:

1) Kain panjang yang dipakai, harus kain batik panjang $(2,25 \mathrm{~m}-2,50 \mathrm{~m})$ dengan tinggi 1 meter 2) Pemakaian kain batik dengan cara dililitkan dan memakai hiasan yang disebut wiron atau wiru atau lipit-lipit selebar $3 \mathrm{~cm}-5 \mathrm{~cm}$ pada akhir lilitan kain

3) Motif batik dapat dipergunakan motif dari daerah manapun. 


\section{b. Sarung:}

1) Kain sarung yang dipakai berukuran

2,5meter dan tinggi 1-1,5meter

2) Pemakaian kain sarung diselubungkan melingkar pada pinggang sampai mata kaki

3) Motif kain sarung dapat dipergunakan motif kotak-kotak dan kotak-kotak yang diselingi benang emas/ perak atau bermotif batik

\section{Akessoris:}

a. Giwang, ukurannya disesuaikan dengan bentuk badan

b.Kalung, ukuran (besar/kecil) dan panjang (panjang/pendek) disesuaikan dengan bentuk badan

c. Bros (1 apabila berukuran besar, 2 apabila berukuran sedang, 3 apabila berukuran kecil). Jenis bros berantai apabila menggunakan bros bersusun

d.Gelang dipergelangan tangan kanan, ukuran dan jumlah disesuaikan dengan bentuk badan dan sifat kesederhanaan penampilan

e. Jam tangan di pergelangan tangan kiri

f. Cincin, modelnya dapat disesuaikan dengan kalung dan giwang

6. Millineries:

a. Selendang :

1) Berbentuk persegi panjang

2) Disimpan di bahu kanan, dan diikat pada pinggul kanan (atau sebaliknya)

3) Dari kain batik atau kain lain (lurik, jumpu tan, batik selungkang, sifon, sutera) yang bertekstur lemas

4) Berwarna kontras atau senada dengan warna kebaya atau salah satu warna yang ada pada kain panjang atau sarung

5) Polos atau dihiasi jumbai, renda, sablon, dan sulam. Sulaman disesuaikan dengan jenis dan bentuk kebaya.

b. Tas :

Model tas dapat digunakan handbag (tas tangan) Warna dan bahan dapat sama dengan warna dan bahan selop, atau sama warnanya dengan selop, atau warna senada

\section{c. Alas kaki :}

1) Selop terbuka atau tertutup pada bagian depan dengan tinggi $2-8 \mathrm{~cm}$

2) Warna dan bahan dapat sama dengan tas, atau warna nya saja yang sama dengan tas atau senada dengan warna antara tas dan selop 3) Hiasan pada selop: sulam, payet, dengan motif di samakan dengan hiasan pada kebaya atau hiasan lain yang serasi dengan kebaya

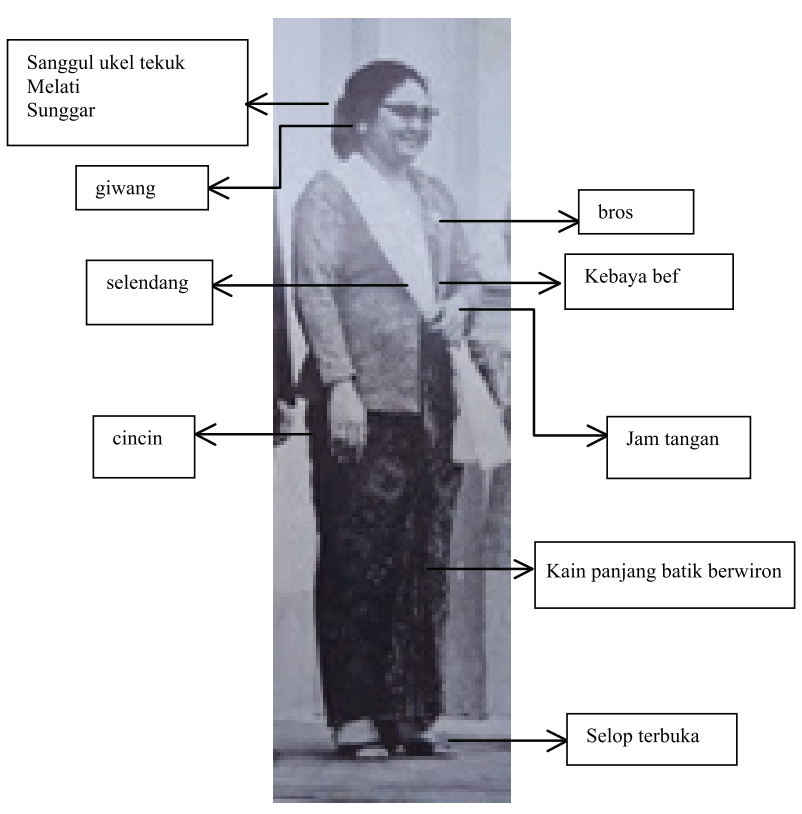

Gambar 7. Busana Kebaya Nasional Ibu Negara seperti di contohkan Ibu Negara Siti Hartinah

\section{SIMPULAN}

1. Busana Kebaya merupakan salah satu jenis gaya berbusana yang berkembang di Indonesia, selain Busana Kebaya Tradisional (busana dearah Indonesia), Busana Kebaya modifikasi atau moderen, dan Busana Kebaya muslimah.

2. Karakteristik Busana Kebaya Nasional dapat diidentifikasi dari faktor:

a) bentuk fisik: berupa sanggul (dibuat sanggul siap pakai), blouse (kebaya) dibuat dengan teknik jahit tertentu (kampuh balik) dan kain panjang berwiron (dilepe)

b) ragam hias: menggunakan ragam hias tradisional Indonesia

c) bahan: bahan untuk kebaya dapat digunakan berbagai jenis tekstil asalkan tidak transparan, sedangkan bahan untuk kain panjang dapat menggunakan berbagai kain tradisional Indonesia

d) ukuran: umumnya kebaya panjangnya sampai panggul (kebaya pendek) dan sampai lutut (kebaya panjang) dengan siluet fit body dan kain panjang sampai mata kaki, sehingga Busana Kebaya Nasional dapat dikatakan sebagai busana yang tertutup

e) cara pakai: terutama sanggul dan kain wiron dibuat secara manual 


\section{DAFTAR RUJUKAN}

Achjadi, Judi, 2003, Permata Cita: Koleksi kain Ibu Negara, Jakarta: Penerbit Himpunan Wastraprema.

Arifah, 2003, Teori Busana, Bandung: Penerbit Yapemdo.

Djoemena, Nian S., 2000, Lurik: Garis-garis Bertuah, Jakarta: PT Ikrar Mandiri Abadi.

Endah, Alberthiene, 2010, Ani Yudhoyono: Kepak Sayap Putri Prajurit, Jakarta: Red and White Publishing.

Forshee, Jill, 2006, Culture and Customs of Indonesia, London: Penerbit Greenwood Press.

Habibie, Bacharuddin Jusuf, 2012, Habibie \& Ainun, Jakarta: PT THC Mandiri.

Kongres Wanita Indonesia (KOWANI), 1986, Sejarah Setengah Abad Kesatuan Pergerakan Wanita Indonesia, Jakarta: Balai Pustaka.

Kusumasundari, Eva, 2014, Iriana Joko Widodo: Ibu Negara Istri Presiden Pilihan Rakyat Harapan di balik Kesederhanaan, Jakarta: SaLaris Publisher.

Kusumawardhani, Reni, 2014, Step by Step 37 Gaya Mari Berkain, Jakarta: Penerbit PT Gramedia Pustaka Utama.

Munandar, 1985, Emansipasi dan Peran Ganda Wanita Indonesia: Suatu Tinjauan Psikologis, Jakarta; Penerbit Universitas Indonesia (UI-Press).
Maeliah, Mally, 2004, Handout Mata Kuliah: BUS 534 Busana Nasional dan Muslimah, JPKK FPTK UPI, tidak diterbitkan

Onggo, Ira Tri, 2013, Falsafah Cinta Sejati Ibu Tien dan Pak Harto, Yogyakarta: Indoliterasi.

Rosidi, Tjetjep Rohendi, 2011, Metodelogi Penelitian Seni, Semarang: Cipta Prima Nusantara.

Sachari, Agus, 2005, Pengantar Metodologi Penelitian Budaya Rupa: Desain, Arsitektur, Seni Rupa dan Kriya, Jakarta: Penerbit Erlangga.

Sedyawati, Edi, 2007, Ke-Indonesia-an dalam Budaya: Buku 1 Kebutuhan Membangun Bangsa yang Kuat, Jakarta; Penerbit Wedatama Widya Sastra.

2010, Budaya Indonesia: Kajian

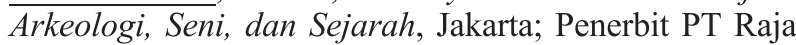
Grafindo Persada.

Sukarno, 1963, Sarinah: Kewajiban Wanita dalam Perdjoangan Republik Indonesia, Panitia Penerbit Bukubuku karangan Presiden Sukarno.

Tilaar, Marthar, 2000, Maximize Your Beauty: panduan Menggali Kecantikan Luar Dalam, Jakarta: Penerbit Creative Stylemandiri.

Zaman, Moh. Alim, 2002, 100 Tahun Mode di Indonesia (1901-2000), Jakarta: Meutia Cipta Sarana \& DPP Ikatan Penata Busana Indonesia "Kartini”. 